\title{
Assessment of Morphological, Physical, Thermal, and Thermal Conductivity Properties of Polypropylene/ Lignosulfonate Blends
}

\author{
Mariane Schneider ${ }^{1}$, Noriê Finimundi ${ }^{1}$, Maria Podzorova ${ }^{2,3} \mathbb{D}$, Petr Pantyukhov ${ }^{2}$ and Matheus Poletto ${ }^{4, *}$ (D) \\ 1 Chemical Engineering, Exact Sciences and Engineering, University of Caxias do Sul (UCS), \\ Caxias do Sul 95070-560, Brazil; msschneider@ucs.br (M.S.); nfinimundi@ucs.br (N.F.) \\ 2 Faculty of Trade Economics and Commodity Science, Plekhanov Russian University of Economics, \\ 117997 Moscow, Russia; mariapdz@mail.ru (M.P.); p.pantyukhov@gmail.com (P.P.) \\ 3 Emanuel Institute of Biochemical Physics, Russian Academy of Sciences, 119991 Moscow, Russia \\ 4 Postgraduate Program in Engineering of Processes and Technologies (PGEPROTEC), Exact Sciences and \\ Engineering, University of Caxias do Sul (UCS), Caxias do Sul 95070-560, Brazil \\ * Correspondence: mpolett1@ucs.br
}

check for updates

Citation: Schneider, M.;

Finimundi, N.; Podzorova, M.;

Pantyukhov, P.; Poletto, M.

Assessment of Morphological,

Physical, Thermal, and Thermal

Conductivity Properties of

Polypropylene/Lignosulfonate

Blends. Materials 2021, 14, 543.

https://doi.org/10.3390/mal14030543

Academic Editor:

Alessandro Pegoretti

Received: 28 December 2020

Accepted: 20 January 2021

Published: 23 January 2021

Publisher's Note: MDPI stays neutral with regard to jurisdictional claims in published maps and institutional affiliations.

Copyright: (C) 2021 by the authors Licensee MDPI, Basel, Switzerland. This article is an open access article distributed under the terms and conditions of the Creative Commons Attribution (CC BY) license (https:// creativecommons.org/licenses/by/ $4.0 /)$.
Abstract: Lignosulfonate is a cheap material available in large quantities obtained as a byproduct of paper and cellulose. In this work, blends of polypropylene (PP) and sodium lignosulfonate (LGNa) were developed to evaluate the potential use of lignosulfonate as a lightweight, thermal insulation and flame retardant material. The blends were obtained by mixing in a torque rheometer and molded after compression. The blend proprieties were evaluated by physical, morphological, thermal, thermal conductivity, and flammability tests. The measured values were compared with theoretical models. The results indicated that a heterogeneous blend with a higher number of separated domains is formed when the LGNa content increases from 10 to $40 \mathrm{wt} \%$. In addition, the density and thermal conductivity coefficient of the blends studied are not affected by the addition of LGNa. However, when the LGNa content in the blend exceeds $20 \mathrm{wt} \%$ the thermal stability and flame retardant proprieties are considerably reduced. The theoretical models based on the rule of mixtures showed a good agreement with the experimental values obtained from blend density, thermal conductivity, and thermal stability. In general, lignosulfonate tested in this work shows potential to be used as a reactive component in polymer blends.

Keywords: blends; polyolefin; characterization

\section{Introduction}

Based on environmental and social concerns such as climate change, global warming, and the growing population in urban areas, government environmental regulations have been encouraging industries to replace inorganic materials by environmentally friendly alternatives [1,2]. The consolidation of the circular economy and the usage of renewable materials can contribute to a more sustainable future [2]. Lightweight materials are an alternative to reduce the fuel consumption in vehicles and can also be used in other engineering fields, such as aerospace applications and construction industry [1-3].

Lignin is the second most abundant natural polymer [4,5]. The lignin content in biomass normally ranged from 10-35\% [4]. Lignin from hardwood or softwood is a byproduct obtained during paper production $[5,6]$. As a natural and renewable material, obtained at an affordable cost, lignin and lignin derivates presented potential to be used as a substitute of inorganic reinforcements in polymeric materials [4-6]. Due to its complex structure formed by several aromatic rings, lignin is a three-dimensional and highly crosslinked macromolecule which has interesting chemical and physical properties $[7,8]$.

Lignin and its derivative products can be obtained from the cellulose and paper industries. The two pulping processes vastly used in the paper industry are the sulfite 
and sulfate (Kraft) process [9,10]. Lignosulfonate is a lignin derivate obtained as a byproduct in the sulfite process while Kraft lignin is obtained from the sulfate process [10]. Lignosulfonates have a higher molecular weight and higher sulfur content than Kraft lignin [9-11]. Budin and Schoenmakers [9] related that only $2 \%$ of the lignin by-products which are obtained by the pulp and paper industries are used commercially [9]. Lignin and lignin derivate products are available in relatively large quantities with a low price [12,13]. The industrial applications of lignosulfonates included low-value products, such as binders and dispersing agents $[12,13]$.

Huang et al. [14] developed biodegradable plastics from mixtures of soy protein isolated and lignosulfonate using glycerol as a plasticizer [14]. The blends were obtained by compression molding. The results indicated that the lignosulfonates content from 30 to 40 parts in the blends improve both the tensile strength and Young's modulus of soy protein alone. The authors also related the lower water absorption from the blends when compared with soy protein. Lin et al. [15] developed a blend of calcium lignosulfonate and biodegradable poly(butylene succinate) (PBS) molded by compression [15]. The authors also observed an increase in the blend rigidity resulting in higher Young's modulus values for blends with $30-50 \mathrm{wt} \%$ of calcium lignosulfonate when compared with PBS. Wang et al. (2016) used maleated lignosulfonate (MLS) produced by esterification with maleic anhydride and unmodified lignosulfonate incorporated into poly(e-caprolactone) (PCL) via melt-blending [16]. The authors also observed an enhancement in the mechanical properties of the blends in comparison with PCL.

As reported in previous studies, the addition of lignosulfonate in polymers can improve the mechanical properties of the blend. This behavior may be associated with the higher rigidity of the lignosulfonate based on its complex chemical structure formed by several aromatic rings in a three dimensional and highly cross-linked macromolecule, similar to the lignin structure. However, numerous works previously evaluated the mechanical properties of polymer lignosulfonate blends. Therefore, the literature lacks studies about other properties of polymer lignosulfonate blends and the usage of these blends to develop lightweight materials that can be used by the construction industries. In this way, this work focuses on the development and characterization of PP/sodium lignosulfonate blends that can be used as office partition panels and wall cladding. The morphological, physical, thermogravimetric, thermal conductivity, and flammability properties of the blends were evaluated and compared with theoretical results.

\section{Materials and Methods}

Polypropylene homopolymer, grade H103, supplied by Braskem (São Paulo, Brazil) with a density of $0.905 \mathrm{~g} / \mathrm{cm}^{3}$ and melt flow index of $40 \mathrm{~g} / 10 \mathrm{~min}\left(230^{\circ} \mathrm{C} / 2.16 \mathrm{~kg}\right)$ was used. Sodium lignosufonate with a commercial name of Ultrazine NA with a mean particle size of $5 \mu \mathrm{m}$ from Borregaard Linotech Brazil was also used to develop the blend.

\subsection{Blend Production}

A Haake torque rheometer was used to the mixture of PP and LGNa. Both components were previously oven-dried at $80^{\circ} \mathrm{C}$ for $4 \mathrm{~h}$. The rotation speed used during the mixture was $60 \mathrm{rpm}$ and occurs at $180^{\circ} \mathrm{C}$. PP was firstly added in the torque rheometer and after its melting LGNa was added. After the LGNa addition, the mixture was processed for $3 \mathrm{~min}$ to better homogenize the polymer blend. The blends were prepared with $10-40 \mathrm{wt} \%$ of LGNa.

The polymer blends were compression molded in sheets with a thickness of $3.2 \mathrm{~mm}$ using a hot press operating at $180^{\circ} \mathrm{C}$ for 3 min at 5 tons.

\subsection{Blend Characterization}

The blend morphology was investigated using scanning electron microscopy in a FEG SEM Tescan Mira 3 (Brno, Czech Republic) at $15 \mathrm{kV}$. The samples were sputter-coated with gold before examination. 
The density of PP and its blends with LGNa were determined in triplicate experiments according to ASTM D792 from the compression molded samples with $2 \times 2 \mathrm{~cm}^{2}$. The void content in the blends were obtained according to ASTM D 2734. The LGNa density was determined in triplicate experiments using a pycnometer based on the ASTM D297 method. The sample was oven-dried at $105^{\circ} \mathrm{C}$ for $48 \mathrm{~h}$ before the test.

The thermal conductivity of PP and its blends with LGNa was obtained in triplicate experiments according to ISO 8302 using the guarded hot plate method. The theoretical models proposed by Bruggeman [17], Botcher [17], and De Loor [17], Equations (1)-(3), respectively, were used for the prediction of the thermal conductivity of PP/LGNa blends.

$$
\begin{gathered}
\mathrm{K}_{\mathrm{b}}=\mathrm{K}_{\mathrm{m}} /(1-\Phi)^{3} \\
\mathrm{~K}_{\mathrm{b}}=\mathrm{K}_{\mathrm{m}} /(1-\Phi) \\
\mathrm{K}_{\mathrm{b}}=\left[\mathrm{K}_{\mathrm{m}}(1+\Phi)\right] /(1-2 \Phi)
\end{gathered}
$$

where $\mathrm{K}_{\mathrm{b}}$ and $\mathrm{K}_{\mathrm{m}}$ are the thermal conductivity of the blend and continuous phase, respectively. $\Phi$ is the volume fraction of the particles.

The thermogravimetric analyses (TGA) of the samples were carried out using a TGA50 (Shimadzu, Kyoto, Japan) in a nitrogen atmosphere at a gas flow rate of $50 \mathrm{~mL} / \mathrm{min}$. A mass sample of approximately $10 \mathrm{mg}$ was used. The temperature range used and heating rate adopted were $23-800{ }^{\circ} \mathrm{C}$ and $10^{\circ} \mathrm{C} / \mathrm{min}$, respectively.

The burning characteristics of PP and its blends with LGNa were evaluated according to the flammability vertical test proposed in the UL 94 standard and ASTM D3801. Samples bars with $127 \times 12.7 \times 3.5 \mathrm{~mm}^{3}$ were used. Five specimens of each sample were tested.

\section{Results and Discussion}

The morphological characteristics of the studied blends can be observed in Figure 1.

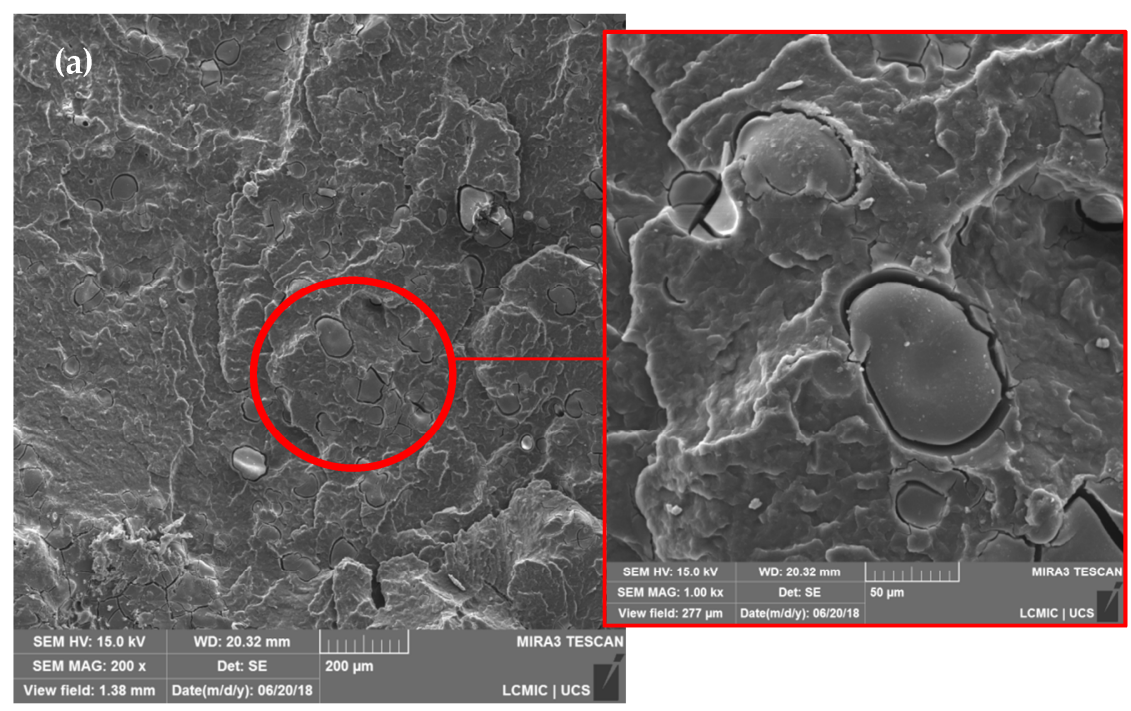

Figure 1. Cont. 

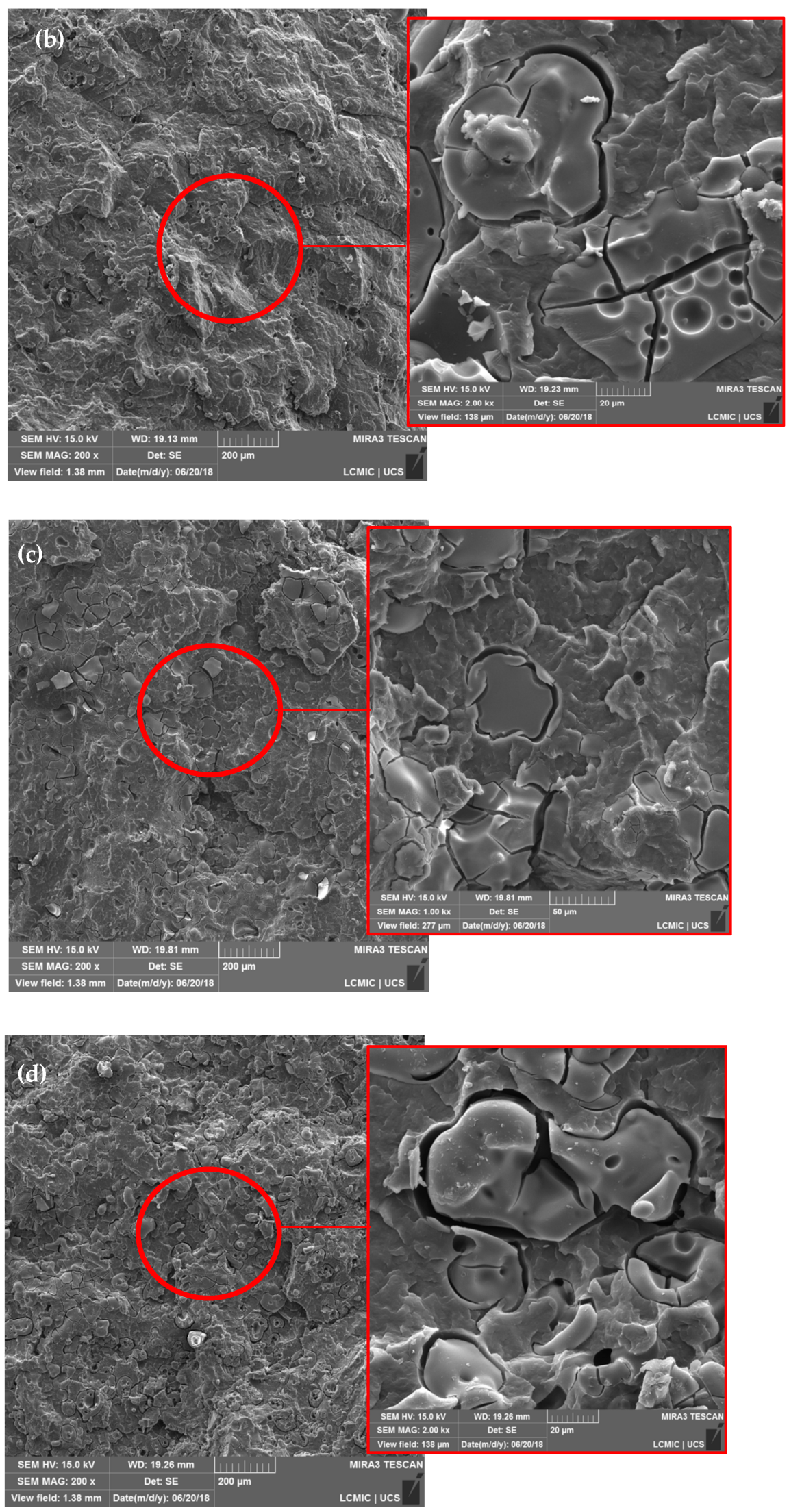

Figure 1. SEM micrographs of polypropylene/sodium lignosulfonate (PP/LGNa) blends with 10 (a), 20 (b), 30 (c), and $40 \mathrm{wt} \%$ (d) of LGNa with magnification of $200 \times$ and detail with magnification of $1000 \times$. 
In general, the lignosulfonate particles are spherical and randomly dispersed in PP without the formation of particle agglomerates. As can be seen in detail in Figure 1, there is a low interfacial adhesion between the PP and LGNa particles. This behavior can be explained by the incompatibility between the hydrophobic PP and higher hydrophilic characteristics of lignosulfonate probably due to the oxygen groups presented on the surface of LGNa. Lignosulfonates are compounds with hydrophobic phenylpropane units and strong hydrophilic sulfonic groups present on the surface of the particles [13,18]. Therefore, the weak interactions between the hydrophobic PP and the polar groups of the LGNa result in the formation of a heterogeneous blend with large dispersed LGNa particles. Cazacu et al. [19] also observed phase separation and an increase in the dimensions of separated domains with increases in the ammonium lignosulfonate content on the ethylenepropylene copolymer blend [19].

The density of LGNa obtained by the pycnometer method was $1.135 \pm 0.003 \mathrm{~g} / \mathrm{cm}^{3}$. The lignin density normally ranges from 1.35 to $1.50 \mathrm{~g} / \mathrm{cm}^{3}$ [20]. The blends theoretical density was determined based on the rule of mixtures and compared with the experimental values [21]. Figure 2 shows the density values for the measured and theoretical density of the blends studied.

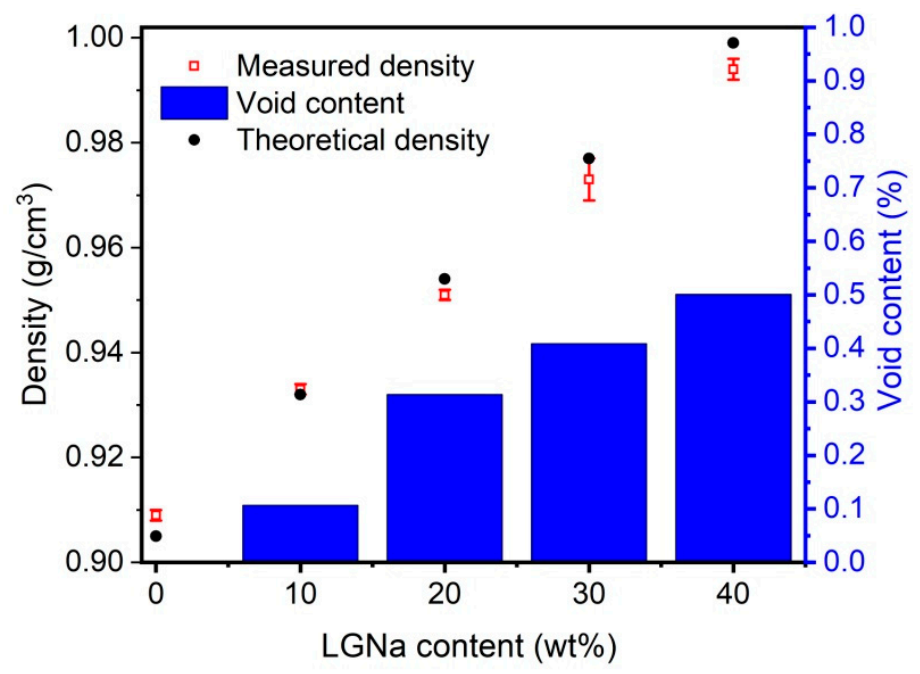

Figure 2. Theoretical and measured density of PP and blends of PP/LGNa showing the void content of all the blends studied.

The LGNa addition from 10 to $40 \mathrm{wt} \%$ linearly increased the blend density, as shown in Figure 2. However, even with the addition of $40 \mathrm{wt} \%$ of lignosulfonate the blend density increased only $10 \%$ when compared with pristine PP. This result indicates that the LGNa addition in PP generates a lightweight material that has potential to be in construction industries. The theoretical density values are very similar to the measured values which indicate that the rule of the mixture can be used to estimate the blend density. The void content increases with the LGNa content in the blend, as shown in Figure 2. This is an expected behavior based on the SEM results presented in Figure 1. As the LGNa content increases, a more pronounced phase separation may occur which results in higher gaps between both phases resulting in a higher void content.

The thermogravimetric results of PP and LGNa particles show distinct processes of weight loss occurring at different temperatures, as shown in Figure 3a. For PP, there is only one degradation step associated with the random cleave of $\mathrm{C}-\mathrm{C}$ bonds, with a higher rate of weight loss temperature $\left(\mathrm{T}_{\max }\right)$ at $432{ }^{\circ} \mathrm{C}$, while LGNa particles show three degradation steps. The first step of weight loss occur between $50-150{ }^{\circ} \mathrm{C}$, with a peak loss rate centered at $100{ }^{\circ} \mathrm{C}$, and can be associated with the absorbed moisture [22]. From the thermogravimetric curve in Figure 3a, it is possible to observe that LGNa starts a more 
pronounced degradation process at around $220^{\circ} \mathrm{C}$ extending to approximately $380{ }^{\circ} \mathrm{C}$, with a $\mathrm{T}_{\max }$ centered at $267^{\circ} \mathrm{C}$. The decomposition of oxygen-containing groups and cleave of C-C bonds occur in this degradation step [22,23]. Some aromatic compounds presented in the lignosulfonate structure such as phenol, guaiacol or syringol, alkyls, some sulfurand/or sodium-containing small molecules were released forming different carbon structures [23]. A last weight loss occurs between $650-750{ }^{\circ} \mathrm{C}$ and might be mainly attributed to the reactions between carbon and sodium-containing inorganic salts associated with the decomposition of residual unstable oxygen containing groups and carbon groups [23].

(a)

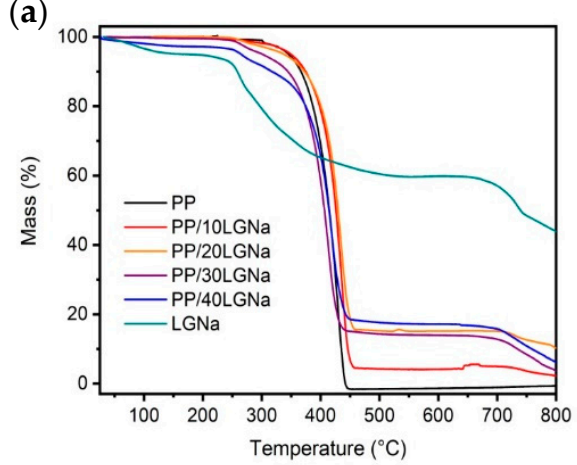

(b)

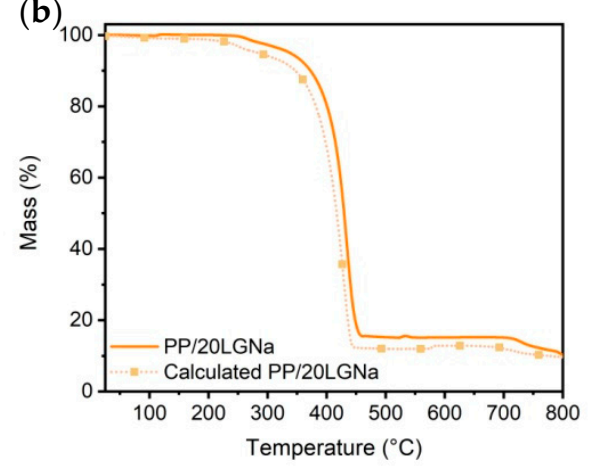

Figure 3. Thermogravimetric curves of PP, LGNa, and its blends (a) and comparison of the expected and experimental thermogravimetric curves of the PP/LGNa blend with $20 \mathrm{wt} \%$ of LGNa (b).

The PP/LGNa blends exhibited two main degradation steps. The first one is attributed to the main degradation of oxygen-containing groups and cleaves of C-C bonds in LGNa, as previously explained, and occurs approximately at the same $\mathrm{T}_{\max }$ observed by LGNa particles. However, the $\mathrm{T}_{\max }$ associated with the PP degradation firstly increases with the addition of 10 and $20 \mathrm{wt} \%$ of LGNa, but decreases with the addition of 30 and $40 \mathrm{wt} \%$ of lignosulfonate, as presented in Table 1. The higher number of separated domains formed when higher quantities of LGNa particles were added and the incompatibility between both materials might contribute to this result. LGNa has a lower thermal stability than PP. When higher quantities of lignosulfonate particles are added, a decomposition process may start at lower temperatures reducing the blend thermal stability. The initial weight loss temperature $\left(\mathrm{T}_{\mathrm{i}}\right)$ considered, in this work, when the sample loses $3 \mathrm{wt} \%$ of its initial mass also corroborate these results, as presented in Table 1 . The $T_{i}$ values considerably decrease as the lignosulfonate content increases in the blend formulation.

Table 1. Temperature parameters evaluated for PP, LGNa, and its blends.

\begin{tabular}{|c|c|c|c|c|}
\hline wt $\%$ PP/wt $\%$ LGNa & $\begin{array}{c}\mathrm{T}_{\mathrm{i}} \text { (3 wt \% Weight Loss) } \\
\left({ }^{\circ} \mathrm{C}\right)\end{array}$ & $\begin{array}{c}\text { Calculated } \mathrm{T}_{\mathrm{i}} \\
\left(3 \mathrm{wt} \% \text { Weight Loss) }\left({ }^{\circ} \mathrm{C}\right)\right.\end{array}$ & $\begin{array}{c}\mathrm{T}_{\max } \mathrm{LGNa} \\
\left({ }^{\circ} \mathrm{C}\right)\end{array}$ & $\begin{array}{c}\mathrm{T}_{\max } \mathrm{PP} \\
\left({ }^{\circ} \mathrm{C}\right)\end{array}$ \\
\hline $100 / 0$ & 332 & - & - & 432 \\
\hline $0 / 100$ & 93 & - & 267 & - \\
\hline $90 / 10$ & 327 & 278 & 267 & 435 \\
\hline $80 / 20$ & 305 & 250 & 266 & 438 \\
\hline $70 / 30$ & 273 & 241 & 268 & 418 \\
\hline $60 / 40$ & 222 & 230 & 266 & 421 \\
\hline
\end{tabular}

The thermogravimetric results obtained from the blends were compared to the calculated curves obtained from the weighted mean of pristine PP and LGNa particles, as shown in Figure 3b. The calculated curve is obtained based on the rule of mixtures as previously proposed by Araújo et al. [24]. In theory, the blends whose curves were located below the calculated curve are less stable than expected, showing antagonistic interactions [24]. On the other hand, the blends whose curves are located above the calculated curve are more 
stable than expected, showing synergistic interactions [24]. The addition of lignosulfonate promotes a synergic effect on the blends thermal stability with 10-30 wt\% of LGNa, as can be seen for the example of the blend with $20 \mathrm{wt} \%$ of LGNa in Figure $3 \mathrm{~b}$. The calculated $\mathrm{T}_{\mathrm{i}}$ values presented in Table 1 for blends with 10-30 wt\% of LGNa are lower than the $\mathrm{T}_{\mathrm{i}}$ values obtained from experimental thermogravimetric curves. This result indicates synergistic interactions between PP and LGNa particles which are responsible for increasing the blend thermal stability. However, when the LGNa content reaches $40 \mathrm{wt} \%$, antagonistic interactions between PP and LGNa occurs. One possible explanation for this is the fact that the blend with $40 \mathrm{wt} \%$ of LGNa presents the highest number of separated domains and also the highest content of oxygen groups at the lignosulfonate surface, which may accelerate the degradation process, reducing the blend thermal stability.

Thermal conductivity can be defined as the material's ability to molecularly transport heat through conduction [25-27]. In polymeric materials, the heat conduction occurs mainly by the vibration and rotation of chain atoms, which can promote the motion of polymer chains $[25,28]$. The thermal conductivity coefficient $(k)$ in thermoplastic composites is affected by the chain structure and orientation, interchain interactions, and crystallinity [25]. When another material is blended with a thermoplastic polymer these parameters may be changed and directly affect the thermal conductivity of the resulting material. On the other hand, thermal conductivity is an important parameter to be considered for the thermal comfort of buildings $[25,29]$. Figure 4 shows the thermal conductivity coefficients measured for PP and its blends with LGNa.

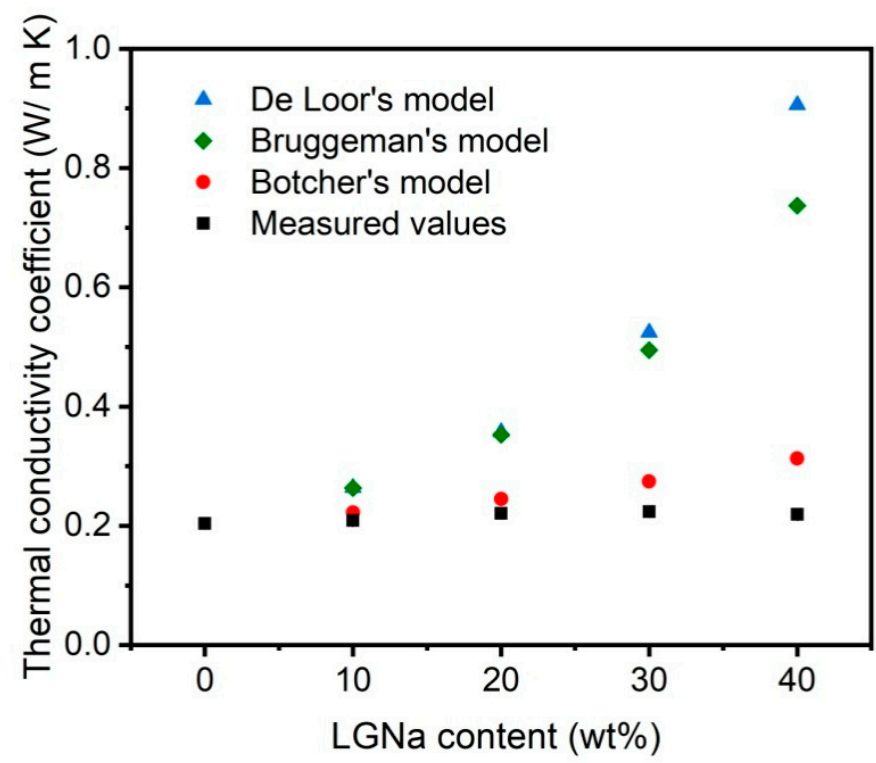

Figure 4. Thermal conductivity coefficients for PP with different contents of LGNa compared with theoretical models.

The measured thermal conductivity coefficient of PP was $0.204 \pm 0.003 \mathrm{~W} / \mathrm{mK}$. PP is a semi-crystalline polymer that can exhibit $k$ values between $0.10-0.25 \mathrm{~W} / \mathrm{mK}$ [25], depending on its crystallinity degree. Ebadi-Dehaghani et al. [17] obtained a $k$ value of $0.22 \pm 0.04 \mathrm{~W} / \mathrm{mK}$ using a guarded heat flow meter method [17]. The addition of LGNa particles did not considerably affect the thermal insulating nature of the PP. The $k$ values from the PP/LGNa blends ranged from $0.209-0.224 \mathrm{~W} / \mathrm{mK}$. Considering the atomic structure of the blends, the main energy transfer occurs by the transport of phonons through the polymer structure, since the free movement of electrons is not possible [25]. The LGNa particles may act as barriers to energy transfer through the PP structure and the separate domains formed due to the incompatibility between PP and LGNa might contribute to maintaining the low thermal conductivity of the blends. In addition, when the LGNa content increased from 30 to $40 \mathrm{wt} \%$, the $k$ value reduced from $0.224 \pm 0.01 \mathrm{~W} / \mathrm{mK}$ 
to $0.219 \pm 0.01 \mathrm{~W} / \mathrm{m}$, which may indicate that the higher number of separated domains formed with a higher content of LGNa particles, as shown in Figure 1d, contributing to the reduction of the energy transfer through the blend.

In general, the blends developed in this study presented an average density of $950 \mathrm{~kg} / \mathrm{m}^{3}$ with a mean thermal conductivity of $0.22 \mathrm{~W} / \mathrm{mK}$. When compared to some materials traditionally used by construction industries such as the gypsum and cement boards, a thermal conductivity of 0.27 and $0.35 \mathrm{~W} / \mathrm{mK}$, respectively, was presented but with a higher density than PP/LGNa blends, ranging from 1033 to $1150 \mathrm{~kg} / \mathrm{cm}^{3}$ [30].

The experimental $k$ values were compared with theoretical values obtained from theoretical models, as shown in Figure 4 . Bottcher's model predicts fairly well the $k$ values until $20 \mathrm{wt} \%$ of LGNa particles. Bottcher's model as also Bruggeman's model assumes that the interactions among the particles can occur according to the increase in the volume fraction of one component, which can directly influence the material thermal conductivity $[31,32]$.

Previous studies related to the potential of lignin and lignin derivates as potential bio-based flame retardants [33,34]. Flammability tests showed that samples with 10 and $20 \mathrm{wt} \%$ of LGNa can be classified as the V-2 category according to ASTM D3801, while PP and blends with 30 and $40 \mathrm{wt} \%$ of LGNa cannot be classified according to this standard. The obtained results are presented in Table 2.

Table 2. Flammability properties of PP and its blends with LGNa particles.

\begin{tabular}{|c|c|c|c|c|c|}
\hline Criteria Conditions & $\mathbf{P P}$ & $90 / 10$ & $80 / 20$ & $70 / 30$ & $60 / 40$ \\
\hline Afterflame time for each individual specimen, $t 1$ or $t 21$ & $\geq 30 \mathrm{~s}$ & $\leq 30 \mathrm{~s}$ & $\leq 30 \mathrm{~s}$ & $\geq 30 \mathrm{~s}$ & $\geq 30 \mathrm{~s}$ \\
\hline $\begin{array}{l}\text { Total afterflame time for any condition set ( } t 1 \text { plus } t 2 \text { for } \\
\text { the five specimens) }\end{array}$ & $\geq 250 \mathrm{~s}$ & $\leq 250 \mathrm{~s}$ & $\leq 250 \mathrm{~s}$ & $\geq 250 \mathrm{~s}$ & $\geq 250 \mathrm{~s}$ \\
\hline $\begin{array}{l}\text { Afterflame plus afterglow time for each individual } \\
\text { specimen after the second flame application }(t 2+t 3)\end{array}$ & $\geq 60 \mathrm{~s}$ & $\leq 60 \mathrm{~s}$ & $\leq 60 \mathrm{~s}$ & $\geq 60 \mathrm{~s}$ & $\geq 60 \mathrm{~s}$ \\
\hline $\begin{array}{c}\text { Afterflame or afterglow of any specimen up to the } \\
\text { holding clamp }\end{array}$ & Yes & No & No & Yes & Yes \\
\hline Cotton indicator ignited by flaming particles or drops & Yes & Yes & Yes & Yes & Yes \\
\hline
\end{tabular}

${ }^{1} t 1$ Afterflame time after the first flame impingement, s, of the $i$ th specimen; $t 2$ afterflame time after the second flame impingement, s, of the $i$ th specimen; and $t 3$ afterflame and afterglow times after the second flame application.

Samples containing 30 and $40 \mathrm{wt} \%$ of LGNa showed greater fluidity during the flammability test when compared with the blends with a lower LGNa content, which favored the total burning of the specimen followed by the flaming drip after the PP flow. The average time for flame extinguishes increases with the LGNa content. Blends containing 10 and $20 \mathrm{wt} \%$ of LGNa presented the mean time for flame extinguish values of 3.2 and $7.6 \mathrm{~s}$, and those containing 30 and $40 \mathrm{wt} \%$, expanded to 34 and $45 \mathrm{~s}$, respectively. This behavior indicates that the LGNa content higher than $20 \mathrm{wt} \%$ does not contribute to improving the performance of the blend as the flame retardant material. When the LGNa content in the blend is higher than $20 \mathrm{wt} \%$ more oxygen groups are in the particle surface which probably enhances the possibility of blend ignition. This behavior is in agreement with the TGA results previously discussed. On the other hand, sodium can react with the degradation products during combustion which may result in the formation of inorganic salts, such as $\mathrm{Na}_{2} \mathrm{CO}_{3}$ and $\mathrm{Na}_{2} \mathrm{SO}_{4}$ [23], and might accelerate the blend thermal decomposition.

\section{Conclusions}

The usage of lignosulfonate in different proportions caused changes in morphological, thermal, thermal conductivity, and flammability properties of the blends studied. The morphological result confirms the formation of a heterogeneous blend with a cracked appearance. The formation of lignosulfonate domains increases with the LGNa content. The blend density and thermal conductivity are not considerably affected by the lignosulfonate addition resulting in a lightweight material with thermal insulation characteristics. The 
thermogravimetric results indicate that the LGNa addition reduces the blend thermal stability. The LGNa tested in this work has the potential to act as a flame retardant. However, its content in the blend cannot exceed $20 \mathrm{wt} \%$. The results obtained from the PP/LGNa blends evaluated in this study encourage the utilization of lignosulfonate as a cheap, lightweight, thermal insulation, and flame retardant material.

Author Contributions: Conceptualization, M.S., N.F., M.P. (Maria Podzorova), P.P., and M.P. (Matheus Poletto); methodology, M.S. and N.F.; formal analysis, M.S., N.F., and M.P. (Maria Podzorova); investigation, M.S., M.P. (Matheus Poletto), and P.P.; resources, M.S.; data curation, M.S.; writing-original draft preparation, M.S., N.F., and M.P. (Maria Podzorova); writing-review and editing, P.P. and M.P. (Matheus Poletto); visualization, P.P.; supervision, M.P. (Matheus Poletto); project administration, M.P. (Matheus Poletto); funding acquisition, M.P. (Matheus Poletto). All authors have read and agreed to the published version of the manuscript.

Funding: This research was funded by Conselho Nacional de Desenvolvimento Científico e Tecnológico (CNPq/Brazil), grant number 435110/2018-7.

Institutional Review Board Statement: Not applicable.

Informed Consent Statement: Not applicable.

Data Availability Statement: The data presented in this study are available on request from the corresponding author.

Acknowledgments: The authors thank Borregaard LignoTech for the supplied sodium lignosulfonate.

Conflicts of Interest: The authors declare no conflict of interest.

\section{References}

1. Michel Murillo, A.; Tutikian, B.F.; Christ, R.; Silva, L.F.O.; Maschen, M.; Leandro Gómez, P.; Oliveira, M.L.S. Analysis of the influence of thickness on fire reaction performance in polyisocyanurate core sandwich panels. J. Mater. Res. Technol. 2020, 9, 9487-9497. [CrossRef]

2. Barbos, J.D.V.; Azevedo, J.B.; Cardoso, P.d.S.M.; da Costa Garcia Filho, F.; del Río, T.G. Development and characterization of WPCs produced with high amount of wood residue. J. Mater. Res. Technol. 2020, 9, 9684-9690. [CrossRef]

3. Watkins, D.; Nuruddin, M.; Hosur, M.; Tcherbi-Narteh, A.; Jeelani, S. Extraction and characterization of lignin from different biomass resources. J. Mater. Res. Technol. 2015, 4, 26-32. [CrossRef]

4. Zhang, X.; Kim, Y.; Eberhardt, T.L.; Shmulsky, R. Lab-scale structural insulated panels with lignin-incorporated rigid polyurethane foams as core. Ind. Crop. Prod. 2019, 132, 292-300. [CrossRef]

5. Parit, M.; Jiang, Z. Towards lignin derived thermoplastic polymers. Int. J. Biol. Macromol. 2020, 165, 3180-3197. [CrossRef] [PubMed]

6. Naseem, A.; Tabasum, S.; Zia, K.M.; Zuber, M.; Ali, M.; Noreen, A. Lignin-derivatives based polymers, blends and composites: A review. Int. J. Biol. Macromol. 2016, 93, 296-313. [CrossRef]

7. Collins, M.N.; Nechifor, M.; Tanasă, F.; Zănoagă, M.; McLoughlin, A.; Stróżyk, M.A.; Culebras, M.; Teacă, C.A. Valorization of lignin in polymer and composite systems for advanced engineering applications-A review. Int. J. Biol. Macromol. 2019, 131, 828-849. [CrossRef]

8. Mainka, H.; Täger, O.; Körner, E.; Hilfert, L.; Busse, S.; Edelmann, F.T.; Herrmann, A.S. Lignin-An alternative precursor for sustainable and cost-effective automotive carbon fiber. J. Mater. Res. Technol. 2015, 4, 283-296. [CrossRef]

9. Brudin, S.; Schoenmakers, P. Analytical methodology for sulfonated lignins. J. Sep. Sci. 2010, 33, 439-452. [CrossRef]

10. Wang, C.; Kelley, S.S.; Venditti, R.A. Lignin-based thermoplastic materials. ChemSusChem 2016, 9, 770-783. [CrossRef]

11. Canetti, M.; Bertini, F. Influence of the lignin on thermal degradation and melting behaviour of Poly(ethylene terephthalate) based composites. ePolymers 2009, 9. [CrossRef]

12. Kun, D.; Pukánszky, B. Polymer/lignin blends: Interactions, properties, applications. Eur. Polym. J. 2017, 93, 618-641. [CrossRef]

13. Lemes, A.P.; Soto-Oviedo, M.A.; Waldman, W.R.; Innocentini-Mei, L.H.; Durán, N. Effect of lignosulfonate on the thermal and morphological behavior of poly(3-hydroxybutyrate-co-3-hydroxyvalerate). J. Polym. Environ. 2010, 18, 250-259. [CrossRef]

14. Huang, J.; Zhang, L.; Chen, F. Effects of lignin as a filler on properties of soy protein plastics. I. Lignosulfonate. J. Appl. Polym. Sci. 2003, 88, 3284-3290. [CrossRef]

15. Yang, Z.; Peng, H.; Wang, W.; Liu, T. Crystallization behavior of poly( $\varepsilon$-caprolactone)/layered double hydroxide nanocomposites. J. Appl. Polym. Sci. 2010, 116, 2658-2667. [CrossRef]

16. Wang, F.; Yang, X.; Zou, Y. Effect of the maleation of lignosulfonate on the mechanical and thermal properties of lignosulfonate/poly( $\varepsilon$-caprolactone) blends. J. Appl. Polym. Sci. 2016, 133, 1-7. [CrossRef] 
17. Ebadi-Dehaghani, H.; Reiszadeh, M.; Chavoshi, A.; Nazempour, M.; Vakili, M.H. The effect of zinc oxide and calcium carbonate nanoparticles on the thermal conductivity of polypropylene. J. Macromol. Sci. Part B 2014, 53, 93-107. [CrossRef]

18. Liu, Y.; Nie, Y.; Lu, X.; Zhang, X.; He, H.; Pan, F.; Zhou, L.; Liu, X.; Ji, X.; Zhang, S. Cascade utilization of lignocellulosic biomass to high-value products. Green Chem. 2019, 21, 3499-3535. [CrossRef]

19. Cazacu, G.; Mihaies, M.; Pascu, M.C.; Profire, L.; Kowarskik, A.L.; Vasile, C. Polyolefin/lignosulfonate blends, 9 functionalized polyolefin/lignin blends. Macromol. Mater. Eng. 2004, 289, 880-889. [CrossRef]

20. Wypych, A. Databook of Adhesion Promoters, 1st ed.; Chem Tech Publishing: Scarborough, ON, Canada, 2018; Chapter 3.14 Lignin; p. B978-B1. [CrossRef]

21. Poletto, M. Effect of styrene maleic anhydride on physical and mechanical properties of recycled polystyrene wood flour composites. Maderas Cienc. Tecnol. 2016, 18, 533-542. [CrossRef]

22. Köhnke, J.; Gierlinger, N.; Mateu, B.P.; Unterweger, C.; Solt, P.; Mahler, A.K.; Schwaiger, E.; Liebner, F.; Gindl-Altmutter, W. Comparison of four technical lignins as a resource for electrically conductive carbon particles. BioResources 2019, 14, $1091-1109$. [CrossRef]

23. Pang, J.; Zhang, W.; Zhang, H.; Zhang, J.; Zhang, H.; Cao, G.; Han, M.; Yang, Y. Sustainable nitrogen-containing hierarchical porous carbon spheres derived from sodium lignosulfonate for high-performance supercapacitors. Carbon 2018, 132, 280-293. [CrossRef]

24. Araújo, J.R.; Waldman, W.R.; De Paoli, M.A. Thermal properties of high density polyethylene composites with natural fibres: Coupling agent effect. Polym. Degrad. Stab. 2008, 93, 1770-1775. [CrossRef]

25. Chaudhry, A.U.; Mabrouk, A.; Abdala, A. Thermally enhanced pristine polyolefins: Fundamentals, progress and prospective. J. Mater. Res. Technol. 2020, 9, 10796-10806. [CrossRef]

26. Burger, N.; Laachachi, A.; Ferriol, M.; Lutz, M.; Toniazzo, V.; Ruch, D. Review of thermal conductivity in composites: Mechanisms, parameters and theory. Prog. Polym. Sci. 2016, 61, 1-28. [CrossRef]

27. Chen, H.; Ginzburg, V.V.; Yang, J.; Yang, Y.; Liu, W.; Huang, Y.; Du, L.; Chen, B. Thermal conductivity of polymer-based composites: Fundamentals and applications. Prog. Polym. Sci. 2016, 59, 41-85. [CrossRef]

28. Zhai, S.; Zhang, P.; Xian, Y.; Zeng, J.; Shi, B. Effective thermal conductivity of polymer composites: Theoretical models and simulation models. Int. J. Heat Mass Transf. 2018, 117, 358-374. [CrossRef]

29. Rizzo, M.; Zeni, M.; Fernanda, M.; Nunes, D.O.; Maria, A. Reacao ao fogo, isolamento t'ermico e desempenhoac'ustico de aglomerados de poliuretano rigido comadicao de fibras naturais. Sci. Cum Ind. 2015, 3, 17-22. [CrossRef]

30. Atsonios, I.; Mandilaras, I.; Founti, M. Thermal assessment of a novel drywall system insulated with VIPs. Energies 2019, $12,2373$. [CrossRef]

31. Kucukdogan, N.; Aydin, L.; Sutcu, M. Theoretical and empirical thermal conductivity models of red mud filled polymer composites. Thermochim. Acta 2018, 665, 76-84. [CrossRef]

32. Odebiyi, O.S.; Onitiri, M.A.; Akinlabi, E.T. Theoretical investigation into the thermal conductivity of particle filled polypropylene composites. Mater. Today Proc. 2018, 5, 74-78. [CrossRef]

33. Costes, L.; Laoutid, F.; Brohez, S.; Dubois, P. Bio-based flame retardants: When nature meets fire protection. Mater. Sci. Eng. $R$ 2017, 117, 1-25. [CrossRef]

34. Costes, L.; Laoutid, F.; Aguedo, M.; Richel, A.; Brohez, S.; Delvosalle, C.; Dubois, P. Phosphorus and nitrogen derivatization as efficient route for improvement of lignin flame retardant action in PLA. Eur. Polym. J. 2016, 84, 652-667. [CrossRef] 